Original Article

\title{
Proper Heat Shock Pretreatment Reduces Acute Liver Injury Induced by Carbon Tetrachloride and Accelerates Liver Repair in Mice
}

\author{
San-Qiang Li1 ${ }^{1 *}$, Dong-Mei Wang ${ }^{1}$, You-Ju Shu², Xue-Dong Wan ${ }^{1}$, Zheng-Shun $\mathrm{Xu}^{1}$, \\ and En-Zhong $\mathrm{Li}^{3}$ \\ ${ }^{1}$ Molecular Medicine Key Laboratory of Liver Injury and Repair, Medical College, Henan University of Science and Technology, An \\ hui road 31, Jian xi district, Luoyang 471003, P.R. China \\ ${ }^{2}$ Department of Environmental Engineering and Chemistry, Luoyang Insititute of Science and Technology, Wang cheng road 90, Luo \\ long district, Luoyang 471023, P.R. China \\ ${ }^{3}$ Department of Biological Engineering, Huanghuai University, Kai yuan road 6, Yi cheng district, Zhumadian 463000, P.R. China
}

\begin{abstract}
Whether proper heat shock preconditioning can reduce liver injury and accelerate liver repair after acute liver injury is worth study. So mice received heat shock preconditioning at $40^{\circ} \mathrm{C}$ for 10 minutes $(\mathrm{min}), 20 \mathrm{~min}$ or $30 \mathrm{~min}$ and recovered at room temperature for 8 hours (h) under normal feeding conditions. Then acute liver injury was induced in the heat shock-pretreated mice and unheated control mice by intraperitoneal (i.p.) injection of carbon tetrachloride $\left(\mathrm{CCl}_{4}\right)$. Hematoxylin and eosin (H\&E) staining, serum aspartate aminotransferase (AST) and alanine aminotransferase (ALT) levels and the expression levels of heat shock protein 70 (HSP70), cytochrome P450 1A2 (CYP1A2) and proliferating cell nuclear antigen (PCNA) were detected in the unheated control mice and heat shock-pretreated mice after $\mathrm{CCl}_{4}$ administration. Our results showed that heat shock preconditioning at $40^{\circ} \mathrm{C}$ for 20 min remarkably improved the mice's survival rate $(\mathrm{P}<0.05)$, lowered the levels of serum AST and ALT ( $\mathrm{P}<0.05)$, induced HSP70 ( $\mathrm{P}<0.01), \mathrm{CYP} 1 \mathrm{~A} 2$ $(\mathrm{P}<0.01)$ and PCNA $(\mathrm{P}<0.05)$ expression, effectively reduced liver injury $(\mathrm{P}<0.05)$ and accelerated the liver repair $(\mathrm{P}<0.05)$ compared with heat shock preconditioning at $40^{\circ} \mathrm{C}$ for $10 \mathrm{~min}$ or $30 \mathrm{~min}$ in the mice after acute liver injury induced by $\mathrm{CCl}_{4}$ when compared with the control mice. Our results may be helpful in further investigation of heat shock pretreatment as a potential clinical approach to target liver injury (DOI: 10.1293/tox.2013-0006; J Toxicol Pathol 2013; 26: 365-373)
\end{abstract}

Key words: heat shock pretreatment, acute liver injury, $\mathrm{CCl}_{4}$, $\mathrm{HSP} 70, \mathrm{CYP} 1 \mathrm{~A} 2$, PCNA

\section{Introduction}

Acute liver failure with massive hepatocellular loss occurs due to various causes. Because liver failure still exhibits high mortality despite intensive care, effective therapeutic approaches are needed ${ }^{1}$. The carbon tetrachloride $\left(\mathrm{CCl}_{4}\right)$-induced acute liver injury model is similar to the human disease from the standpoint of morphology and biochemical aspects of collagen metabolism. A single dose or very few doses result in acute liver damage that has been widely employed to study morphological and biochemical features of cellular lesions, especially steatosis and necro$\mathrm{sis}^{2}$. At an early stage after $\mathrm{CCl}_{4}$ administration, transient increases in the expression of the stress-inducible HSP70

Received: 1 February 2013, Accepted: 16 July 2013

*Corresponding author: S-Q Li (e-mail: sanqiangli2001@163.com)

(C)2013 The Japanese Society of Toxicologic Pathology

This is an open-access article distributed under the terms of the Creative Commons Attribution Non-Commercial No Derivatives (by-ncnd) License $<$ http://creativecommons.org/licenses/by-nc-nd/3.0/ $>$. gene occur ${ }^{3}$. HSP70 knockout mice have a higher degree of necrosis and neutrophilic infiltration than normal mice. So HSP70 could play an important role in the cytoprotection of the liver against hepatotoxic agents ${ }^{2}$. Heat shock preconditioning induces HSP72 in the rat liver with fibrosis and provides significantly increased tolerance to warm ischemia-reperfusion injury ${ }^{4}$. Hagiwara et al. $(2007)^{5}$ reported that thermal pretreatment is associated with the induction of HSP70 protein synthesis, which subsequently attenuates tissue damage in experimental lung fibrosis.

Heat shock can cause cell death if cellular defense mechanisms are insufficient to cope with the stress. This is particularly obvious when the temperature increases well above that of the normal environment and/or exposure time is prolonged. An important feature of HSPs is their role in the cytoprotection and repair of cells and tissues with regard to the harmful effects of stress ${ }^{6,7}$. The major families of mammalian stress proteins, HSP90 and HSP70, as well as the smaller HSP28 family, have all been well characterized $^{5}$. HSP70 overexpression confers myocardial protection, as observed by resistance to myocardial ischemic stress and 
reperfusion damage ${ }^{8-10}$. In a rodent model for adult respiratory distress syndrome, heat shock-induced HSP70 accumulation within the lung has been associated with decreased pulmonary inflammation and prevention of lethality ${ }^{11}$. The cytoprotective role of HSP70 has also been documented in the areas of metabolic disorders ${ }^{12}$, and infection ${ }^{13}$. These observations suggest new therapeutic strategies relying upon the development of methods that are able to increase the expression of HSPs. Furthermore, it has been shown that the production of HSPs could protect the organism against a second exposure to otherwise lethal hyperthermia, which has been described as the thermotolerance phenomenon ${ }^{14}$.

Whether proper heat shock preconditioning can reduce liver injury and accelerate liver repair after acute liver failure induced by $\mathrm{CCl}_{4}$ is worth study. Our previous study showed that heat shock at a lower temperature (heat shock at $40^{\circ} \mathrm{C}$ for $20 \mathrm{~min}$ ) significantly promotes hepatocyte proliferation and improves metabolic efficiency in the mouse liver, while heat shock at a higher temperature (heat shock at $46^{\circ} \mathrm{C}$ for $20 \mathrm{~min}$ ) remarkably inhibits hepatocyte proliferation, promotes hepatocyte apoptosis and induces liver injury $^{15}$. So we selected a proper temperature and time to study whether proper heat shock preconditioning could reduce liver injury and accelerate liver repair after acute liver failure induced by $\mathrm{CCl}_{4}$.

\section{Materials and Methods}

\section{Animals}

Male BALB/c mice are sensitive to temperature, and it is easy to induce acute liver injury in them using $\mathrm{CCl}_{4}$; so male BALB/c mice (approximately $6-8$ weeks old, $22 \pm$ $2 \mathrm{~g}$ ) were purchased from the Experimental Animals Center of Henan Province and maintained in an air-conditioned animal room at $25^{\circ} \mathrm{C}$ with free access to water and food under $12 \mathrm{~h}$ light/dark cycles for the experiments. All animals were allowed to adapt to the environment for 1 week before the experiment and were fed laboratory chow. All protocols conformed to the guidelines of the National Animal Care and Use Committee of China. All animals received care in compliance with the Principles of Laboratory Animal Care.

\section{Heat shock preconditioning and acute liver injury induced by $\mathrm{CCl}_{4}$}

Our previous work suggested that heat shock at $40^{\circ} \mathrm{C}$ for $20 \mathrm{~min}$ is a proper condition for heat shock preconditioning because it could effectively promote hepatocyte proliferation and improves the metabolic efficiency in the mouse liver ${ }^{15}$. So mice were anesthetized with urethane (1.4 $\mathrm{g} / \mathrm{kg}$, i.p.) and divided into two groups. In the heat shock group (HS20 group, $\mathrm{n}=90$ ), mice received heat shock preconditioning at $40^{\circ} \mathrm{C}$ for $20 \mathrm{~min}$ and subsequent $\mathrm{CCl}_{4}$ (analytical reagent, from Tianjin Kaitong Chemical Reagent Co., Ltd; Tianjin, China) administration. The mice in the control group ( $\mathrm{n}=90)$ were only injected with $\mathrm{CCl}_{4}$ to induce acute liver injury. Briefly, mice in the HS20 group were placed in a temperature-controlled ventilated and humidified cham- ber to raise the rectal temperature to $40^{\circ} \mathrm{C}$ for $20 \mathrm{~min}$, which was monitored by a digital thermometer in the rectum. The animals were then allowed to recover at room temperature in normal feeding conditions. At $8 \mathrm{~h}$ after heat shock pretreatment, $0.1 \% \mathrm{CCl}_{4}\left(1 \mu \mathrm{CCl}_{4}\right.$ in $1 \mathrm{ml}$ mineral oil $)$ was administered to the mice in group HS20 and the control group by i.p. injection of $10 \mathrm{~mL} / \mathrm{Kg}$. Blood was drawn via the orbital vein at $0,3,6,12,24,30,36,42,48$ and $54 \mathrm{~h}$ in the mice of the two groups after $\mathrm{CCl}_{4}$ injection. The coagulated blood was left to clot at room temperature for approximately 15 to $30 \mathrm{~min}$. After it was completely clotted, it was rimmed using an applicator stick and then centrifuged for approximately 5-10 min at $2500 \mathrm{rpm}$. Then the supernatant fluid was separated. Serum AST and ALT activities were determined with a commercial assay kit (Nanjing Jiancheng Biological Technology, Inc., Nanjing, China) at 0, 3, 6, 12, $24,30,36,42,48$ and $54 \mathrm{~h}$ in the mice of the two groups after $\mathrm{CCl}_{4}$ injection. Enzyme activities were expressed as an international unit per liter (IU/L). The mice at each time point in each group were divided into three subgroups 1,2 and 3. Each subgroup contained three mice. We also performed an experiment in which mice received heat shock preconditioning at $40^{\circ} \mathrm{C}$ for $10 \mathrm{~min}$ (HS10 group, $\mathrm{n}=90$ ) or 30 min ( $\mathrm{HS} 30$ group, $\mathrm{n}=90$ ) and subsequent $\mathrm{CCl}_{4}$ administration. In addition, we performed a parallel experiment and only evaluated the survival rate in heat shock-pretreated mice and control mice after $\mathrm{CCl}_{4}$ injection.

\section{Histologic examination}

Liver specimens were obtained from 9 mice at each time point. Each liver specimen from each mouse was divided into two sections. One was used for histologic examination, and the other was used for Western blot detection. Samples of liver were fixed in $10 \%$ formaldehyde for $24 \mathrm{~h}$ and then dehydrated and embedded in paraffin. Six-micrometer sections were cut from each paraffin-embedded tissue and stained with hematoxylin and eosin (H\&E). To evaluate the degree of necrosis after acute liver injury, we created an injury grading score (Grade $0-4$ ) based on severity of necrotic lesions in the liver parenchyma ${ }^{16}$. The grades were as follows: Grade 0, no pathological change; Grade 1, presence of degenerated hepatocytes with only rare foci of necrosis; Grade 2, small area of mild centrilobular necrosis around the central vein; Grade 3, area of mild centrilobular necrosis severer than Grade 2; and Grade 4, centrilobular necrosis severer than Grade 3. Every group contains three subgroups 1, 2 and 3. Each subgroup contains three mice.

\section{Immunohistochemistry for HSP70, CYP1A2 and PCNA}

Six-micrometer sections were cut from each paraffinembedded tissue as prepared above. The sections of liver from the mice in different groups were immunostained with a monoclonal antibody to mouse HSP70, CYP1A2 and PCNA (dilution 1:300) (Santa Cruz) as described by Xu et al. $(2000)^{17}$. The signal was detected using the Polink-2 plus polymer HRP detection system (Zhongshan, Beijing, China) 
using DAB. A negative control was carried out on each slide by omitting the primary antibody. Sections were examined microscopically for specific staining and photographs were taken using a digital image-capture system (Olympus, Tokyo, Japan). Numbers of positive cells from the control and preheated mice were $12 \mathrm{~mm}^{2}$ tissue sections counted for each mouse.

\section{Western blot of HSP70, CYP1A2 and PCNA}

HSP70 play important roles in stress response, and CYP1A2 principally participates in metabolizing chemicals and environmental toxins in the liver. PCNA has been shown to be a good marker to distinguish proliferating cells ${ }^{17,18}$. So the expression levels of HSP70, CYP1A2 and PCNA were detected by Western blot to compare liver stress response, metabolism and regeneration in heat shock-pretreated mice and control mice after $\mathrm{CCl}_{4}$ administration. Protein samples of $70 \mu \mathrm{g}$ from the mice in the different groups were adjusted to the composition of the electrophoresis sample buffer (50 $\mathrm{mM}$ Tris, $\mathrm{pH} 6.8,10 \%$ glycerol, 5\% beta-mercaptoethanol, $2 \%$ SDS, $0.1 \%$ bromphenol blue) and boiled for 5 min prior to analysis. SDS-PAGE (10\% polyacrylamide gels) in $1 \mathrm{~mm}$ slab gel was performed as described by Sambrook and Russell $(2001)^{19}$. The proteins were transferred from the gel to nitrocellulose membranes. Then the membrane was probed with a monoclonal antibody to mouse HSP70, CYP1A2 or PCNA (Santa Cruz), respectively. The signal was detected by a horseradish peroxidase detection system using DAB (Sigma). Protein bands were quantified with the Gel-Pro Analyzer 4.0 software (Media Cybernetics Inc., Bethesda, MD, USA), and the intensities of the bands were normalized against $\beta$-actin. Every experiment was repeated three times.

\section{Statistical analysis}

The data were presented as means \pm SEM of 9 animals per group at each time point. Statistical comparisons were made using one-way and two-way (without interaction) ANOVA with the Tukey post-hoc test for multiple comparisons. All statistical analyses were performed using SPSS 14.0 (SPSS Inc., Chicago, IL, USA). Survival rates of mice were analyzed using the log-rank test and expressed as Kaplan-Meier survival curves.

\section{Results}

\section{Alterations in the serum AST and ALT levels and sur-} vival rate in the mice

Figure 1 shows that the maximum levels of serum AST and ALT were observed at $24 \mathrm{~h}$ post- $\mathrm{CCl}_{4}$ injection in the control group, but at $30 \mathrm{~h}$ in the mice with heat shock pretreatment at $40^{\circ} \mathrm{C}$ for $20 \mathrm{~min}$ (HS20 group). In addition, the peak values were approximately 1.9 -fold higher in the control group than in the HS20 group. In the control group, the AST and ALT values decreased from $30 \mathrm{~h}$ post- $\mathrm{CCl}_{4}$ injection, reaching the basal value at $54 \mathrm{~h}$, while the AST and ALT values decreased from $36 \mathrm{~h}$ post- $\mathrm{CCl}_{4}$ injection, reaching the basal value at $48 \mathrm{~h}$ observed in the HS20 group. In
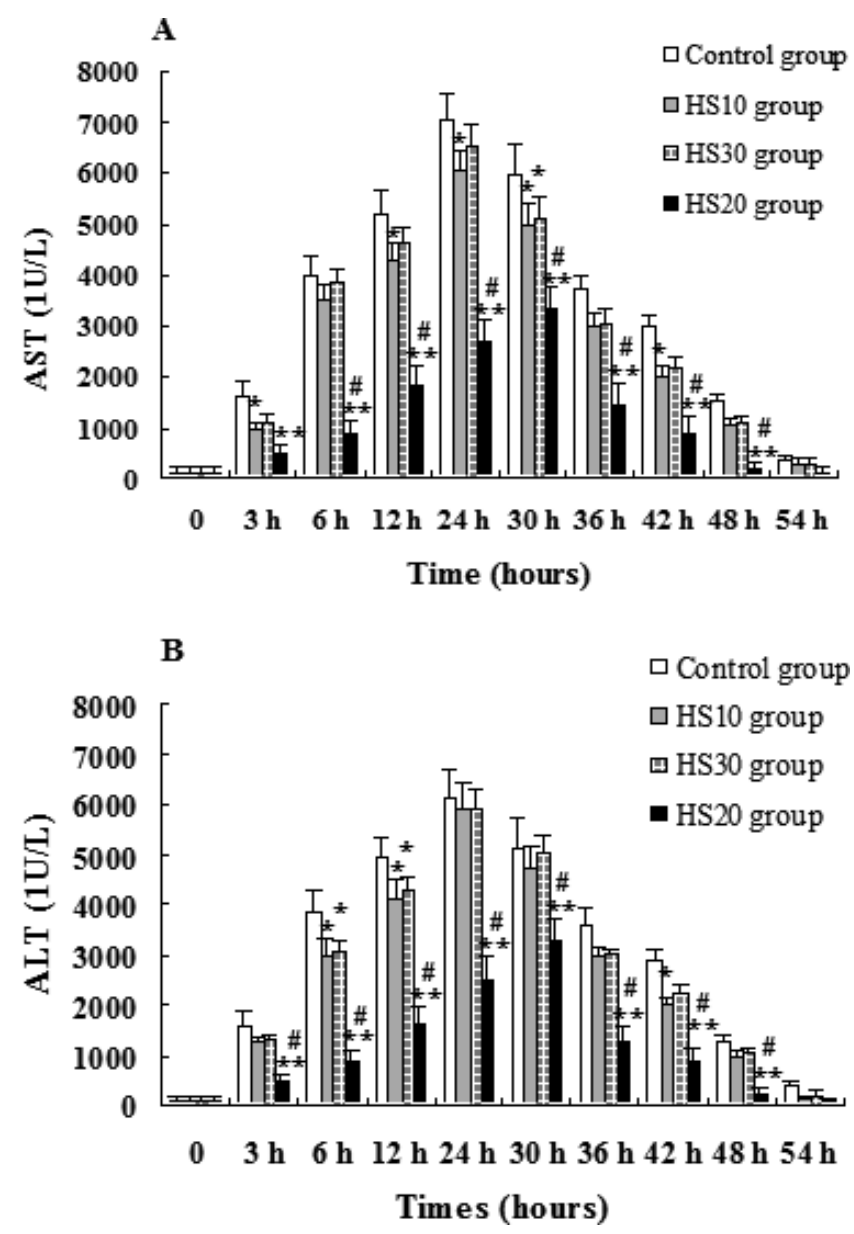

Fig 1. Serum AST (A) and ALT (B) levels in the mice of the control and pretreatment groups at $0,3,6,12,24,30,36,42$, 48 and $54 \mathrm{~h}$ after administration of $0.1 \mathrm{ml} / 10 \mathrm{~g} 0.1 \% \mathrm{CCl}_{4}(1$ $\mu \mathrm{l} \mathrm{CCl}$ in $1 \mathrm{ml}$ mineral oil). Data are expressed as means \pm SEM ( $\mathrm{n}=9)$. HS10 group, HS20 group and HS30 group: mice received heat shock preconditioning with $40^{\circ} \mathrm{C}$ for 10,20 and $30 \mathrm{~min}$, respectively and then recovered at room temperature for $8 \mathrm{~h}$ under normal feeding conditions; $0.1 \% \mathrm{CCl}_{4}$ was subsequently administered to the mice. Control group: mice were only administered $0.1 \% \mathrm{CCl}_{4} * P<0.05$; ** $P<0.01$; significant difference in the HS group as compared with the control group. ${ }^{\#} \mathrm{P}<0.05$ when compared with the HS10 and HS30 groups.

addition, the AST and ALT levels in the control group were significantly higher than those in the HS20 group at each time point from $3 \mathrm{~h}$ to $48 \mathrm{~h}$ post $\mathrm{CCl}_{4}$ injection $(P<0.01)$. The AST and ALT levels in the HS10 group and HS30 group were lower than those in the control group at some time points post $\mathrm{CCl}_{4}$ injection $(P<0.05)$, but the time points at which the peak levels of serum AST and ALT were reached in the HS10 group and HS30 group were similar to those in the control group post $\mathrm{CCl}_{4}$ injection (Fig. 1). The preheated animals showed a marked increase in survival rate (94.4\%) in the HS20 group compared with the unheated control group $(74.4 \%)$ at $54 \mathrm{~h}$ after $\mathrm{CCl}_{4}$ injection $(P<0.05)$. But the survival rates of the HS10 group (80\%) and HS30 group 


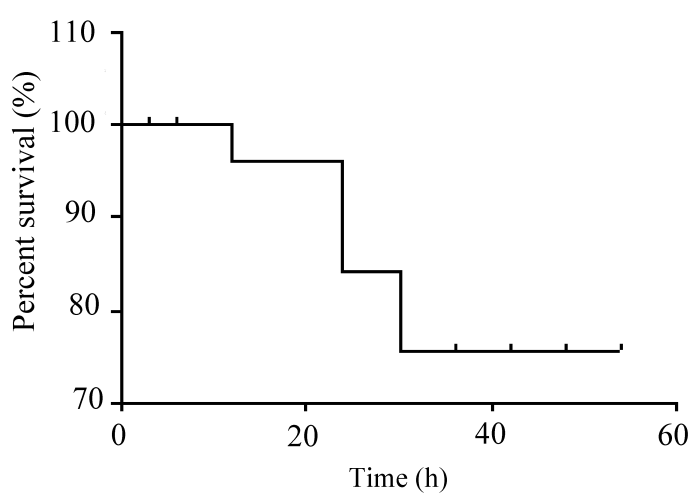

A. Control group

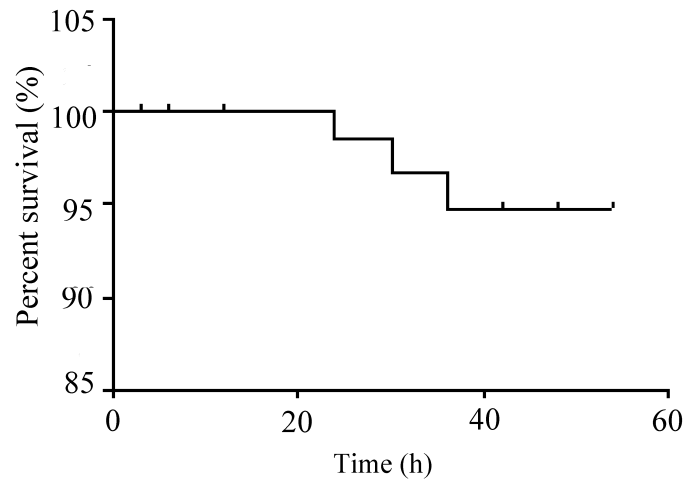

C. HS20 group

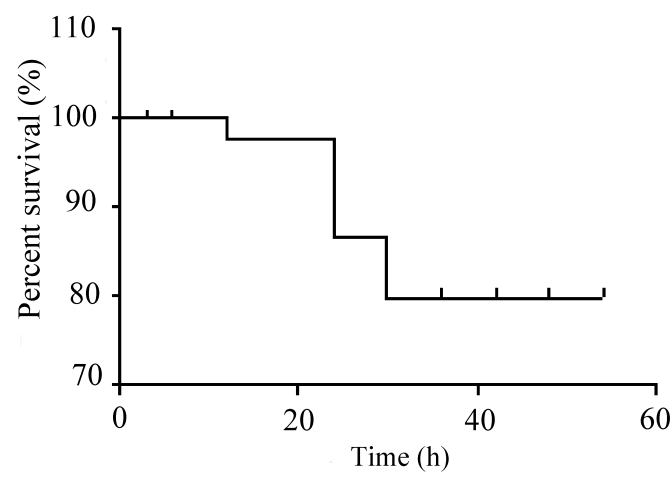

B. HS10 group

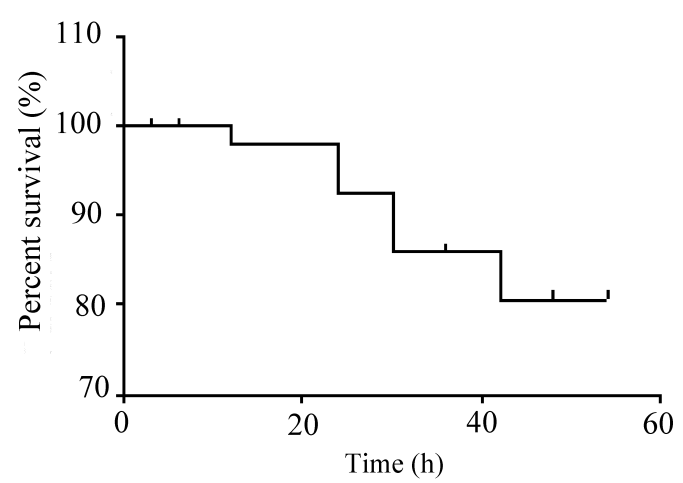

D. HS30 group

Fig. 2. The effect of heat shock pretreatment on the survival rate of mice in which liver injury was induced by $\mathrm{CCl}_{4}$ A, B, C and D, respectively, represent the survival rates of mice in the control group, HS10 group, HS20 group and HS30 group at $0,3,6,12,24,30,36,42,48$ and $54 \mathrm{~h}$ after exposure to $0.1 \mathrm{ml} / 10 \mathrm{~g} 0.1 \% \mathrm{CCl}_{4}(1$ $\mu \mathrm{CCl}_{4}$ in $1 \mathrm{ml}$ mineral oil). The results were analyzed using the log-rank test and expressed as KaplanMeier survival curves. The data show that the survival rate of the HS20 group was significantly improved compared with the HS10 group and the HS30 group when compared with the control group $(P<0.05)$.

$(80 \%)$ were not significantly improved compared with the unheated control group at $54 \mathrm{~h}$ after $\mathrm{CCl}_{4}$ injection $(P>0.05)$ (Fig. 2).

\section{Histological changes in heat shock-pretreated mice and control mice with acute liver injury induced by $\mathrm{CCl}_{4}$}

To evaluate liver injury degree, H\&E staining was performed in the liver of mice. Table 1 and Fig. 3 show that heat shock pretreatment at $40^{\circ} \mathrm{C}$ for 20 min significantly reduced liver injury degree compared with the control mice when acute liver injury was induced by $\mathrm{CCl}_{4}(P<0.01)$. Heat shock pretreatment at $40^{\circ} \mathrm{C}$ for 20 min not only postponed the peak of liver injury but also accelerated repair of liver injury (Table 1) $(P<0.01)$. But heat shock pretreatment at $40^{\circ} \mathrm{C}$ for $10 \mathrm{~min}$ or $30 \mathrm{~min}$ did not significantly ameliorate liver injury induced by $\mathrm{CCl}_{4}(P>0.05)$ (Table 1 and Fig. 3).
The expression of HSP70, CYP1A2 and PCNA in the liver of mice

The expression of HSP70 in the liver of the HS20 group was significantly higher than those in the control group $(P<0.01)$ and HS10 and HS30 groups $(P<0.01)$ from $0 \mathrm{~h}$ to $54 \mathrm{~h}$ after $\mathrm{CCl}_{4}$ injection. But the expression of HSP70 in the HS10 and HS30 groups was only higher than that in the control group from $0 \mathrm{~h}$ to $3 \mathrm{~h}$ after $\mathrm{CCl}_{4}$ injection $(P<0.05)$ (Figs. 4, 7A and 7B). From $0 \mathrm{~h}$ to $54 \mathrm{~h}$ after $\mathrm{CCl}_{4}$ administration, the expression of CYP1A2 in the HS20 group was always higher than that in the control group $(P<0.01)$ and was higher than that in the HS10 and HS30 groups at subtotal time points $(P<0.05)$, except at $12 \mathrm{~h}$ and $30 \mathrm{~h}$ after $\mathrm{CCl}_{4}$ administration. The expression of CYP1A2 in the HS10 and HS30 groups was higher than that in the control group at major time points $(P<0.05)$, except at $24 \mathrm{~h}$ and 36 $\mathrm{h}$ after $\mathrm{CCl}_{4}$ injection (Figs. 5, 7A and 7C). The expression of PCNA in the liver of heat shock-pretreated mice reached the minimum level at $12 \mathrm{~h}$ and then increased at $24 \mathrm{~h}$ to $48 \mathrm{~h}$ when liver regeneration started after liver injury. On the other hand, the expression of PCNA in the liver of the 
Table 1. Liver Injury Degree

\begin{tabular}{|c|c|c|c|c|c|c|c|c|c|c|}
\hline Group of mice & $0 \mathrm{~h}$ & $3 \mathrm{~h}$ & $6 \mathrm{~h}$ & $12 \mathrm{~h}$ & $24 \mathrm{~h}$ & $30 \mathrm{~h}$ & $36 \mathrm{~h}$ & $42 \mathrm{~h}$ & $48 \mathrm{~h}$ & $54 \mathrm{~h}$ \\
\hline \multicolumn{11}{|l|}{ Control group } \\
\hline 1 & 0 & 1 & $2-3$ & 3 & 4 & $2-3$ & 2 & $1-2$ & $1-2$ & 1 \\
\hline 2 & 0 & 1 & 2 & 3 & $3-4$ & 3 & $2-3$ & $1-2$ & 1 & 0 \\
\hline 3 & 0 & 1 & 2 & $2-3$ & 4 & 3 & 2 & $1-2$ & 1 & 0 \\
\hline \multicolumn{11}{|l|}{ HS10 group } \\
\hline 1 & 0 & $0-1$ & $2-3$ & $2-3$ & 4 & 3 & $2-3$ & $1-2$ & $1-2$ & 0 \\
\hline 2 & 0 & 1 & $2-3$ & 3 & $3-4$ & $2-3$ & $2-3$ & $1-2$ & 1 & 1 \\
\hline 3 & 0 & 1 & 2 & $2-3$ & $3-4$ & 3 & 2 & 1 & 1 & 1 \\
\hline \multicolumn{11}{|l|}{ HS20 group } \\
\hline 1 & 0 & $0-1 *$ & $1^{* *}$ & $1-2 * *$ & $2 * *$ & $2-3 *$ & $1-2 *$ & $0-1 * *$ & 0 ** & 0 \\
\hline 2 & 0 & $0-1$ & $1^{* *}$ & $1-2 * *$ & $2 * *$ & 3 & $1-2^{*}$ & $0-1^{* *}$ & $0 * *$ & 0 \\
\hline 3 & 0 & $0^{* *}$ & $0-1^{* *}$ & $1^{* *}$ & $2 * *$ & $2-3^{*}$ & 2 & $1^{*}$ & $0-1^{*}$ & 0 \\
\hline \multicolumn{11}{|l|}{ HS30 group } \\
\hline 1 & 0 & 1 & 2 & 3 & $3-4$ & 3 & $2-3$ & 1 & 1 & 0 \\
\hline 2 & 0 & 1 & 2 & $2-3$ & 4 & 3 & 2 & $1-2$ & 1 & 0 \\
\hline 3 & 0 & $0-1$ & $2-3$ & 3 & 4 & $2-3$ & 2 & $1-2$ & $1-2$ & 1 \\
\hline
\end{tabular}

Time (hours) after $0.1 \% \mathrm{CCl}_{4}\left(1 \mu \mathrm{CCl}_{4}\right.$ in $1 \mathrm{ml}$ mineral oil) i.p. injection in the mice. Injury degree according to severity of necrosis in the liver parenchyma: Grade 0 , no pathological change; Grade 1, presence of degenerated hepatocytes with only rare foci of necrosis; Grade 2, small area of mild centrilobular necrosis around the central vein; Grade 3, area of mild centrilobular necrosis severer than Grade 2; and Grade 4, centrilobular necrosis severer than Grade 3. HS10 group, HS20 group and HS30 group: mice respectively received heat shock preconditioning at $40^{\circ} \mathrm{C}$ for $10 \mathrm{~min}, 20 \mathrm{~min}$ and $30 \mathrm{~min}$, then recovered at room temperature for $8 \mathrm{~h}$ and subsequently received $\mathrm{CCl}_{4}$ administration. Control group: mice only received $\mathrm{CCl}_{4}$ administration. Every group contains three subgroups 1,2 and 3 . Every subgroup contains three mice. $* P<0.05$; $* * P<0.01$; significant difference in the HS group as compared with the control group.

control mice reached the minimum level at $24 \mathrm{~h}$ and then increased from $30 \mathrm{~h}$ to $54 \mathrm{~h}$ after liver injury. In addition, the expression level of PCNA in the heat shock-pretreated mice was significantly higher than that in the control mice after $\mathrm{CCl}_{4}$ administration at each time point from $0 \mathrm{~h}$ to $54 \mathrm{~h}$ $(P<0.05)$. But heat shock pretreatment at $40^{\circ} \mathrm{C}$ for $10 \mathrm{~min}$ or 30 min did not significantly induce the expression of PCNA $(P>0.05)$ after liver injury induced by $\mathrm{CCl}_{4}$ when compared with the control mice (Figs. 6, 7A and 7D).

\section{Discussion}

Our results suggested that proper heat shock pretreatment, such as $40^{\circ} \mathrm{C}$ for $20 \mathrm{~min}$, could significantly induce HSP70, CYP1A2 and PCNA expression (Figs. 4-7), reduce liver injury and accelerate liver repair (Table 1 and Fig. 3) after liver injury induced by $\mathrm{CCl}_{4}$ in mice.

It has been reported that thermal pretreatment is associated with the induction of HSP70 protein synthesis, which subsequently attenuates acute lung injury induced by lipopolysaccharide in rats ${ }^{5}$. But whether heat shock pretreatment can reduce acute liver injury induced by $\mathrm{CCl}_{4}$ in mice has not been studied. Based on the results of analysis in a previous study ${ }^{15}$ (Li et al., 2012), we think that heat shock at $40^{\circ} \mathrm{C}$ for $20 \mathrm{~min}$ is an optimal thermal pretreatment to induce HSP70 expression and improve liver function compared with heat shock at $42^{\circ} \mathrm{C}, 44^{\circ} \mathrm{C}$ and $46^{\circ} \mathrm{C}$ for $20 \mathrm{~min}$. So mice received heat shock preconditioning at $40^{\circ} \mathrm{C}$ for 20 $\min$ (HS20 group) and subsequent $\mathrm{CCl}_{4}$ administration. Figure 1 shows that heat shock preconditioning at $40^{\circ} \mathrm{C}$ for 20 min effectively lowered serum AST and ALT levels in the mice with acute liver injury induced by $\mathrm{CCl}_{4}$ compared with heat shock preconditioning at $40^{\circ} \mathrm{C}$ for $10 \mathrm{~min}$ or $30 \mathrm{~min}$ as compared with the control mice $(\mathrm{P}<0.01)$, which indicated that heat shock preconditioning at $40^{\circ} \mathrm{C}$ for 20 min could effectively reduce liver injury induced by $\mathrm{CCl}_{4}$ (Table 1 and Fig. 3) and improve the survival rate (Tablel and Fig. 2) in the mice. Saad et al. $(1995)^{14}$ reported that heat exposure associated with HSP induction has a significant protective effect against warm ischemic liver injury. Yang et al. (1998) $)^{20}$ reported that heat shock protein expression protects against death following exposure to heatstroke in rats. Although the HSPs were associated with the phenomenon of thermotolerance, cross protection against other kinds of cellular stress, the underlying mechanism of this protection is not clear. The function of HSP has been explained by an improved transportation of repair proteins across cellular and subcellular membranes, preventing intracellular calcium overload and an increased catalase activity. It has been speculated that HSPs reduce the oxidative injury caused by oxygen free radicals that occurs during the early phase of reperfusion ${ }^{14,21}$. So we think that heat shock pretreatment significantly induced HSP70 expression (Figs. 4, 7A and 7B), which is the cellular response to oxidative stress, and provided protection against oxygen distress in acute liver injury induced by $\mathrm{CCl}_{4}$ in the mice.

Our results also showed that heat shock pretreatment at $40^{\circ} \mathrm{C}$ for $20 \mathrm{~min}$ could significantly induced CYP1A2 expression compared with heat shock pretreatment at $40^{\circ} \mathrm{C}$ for $10 \mathrm{~min}$ or $30 \mathrm{~min}$ when compared with control mice 

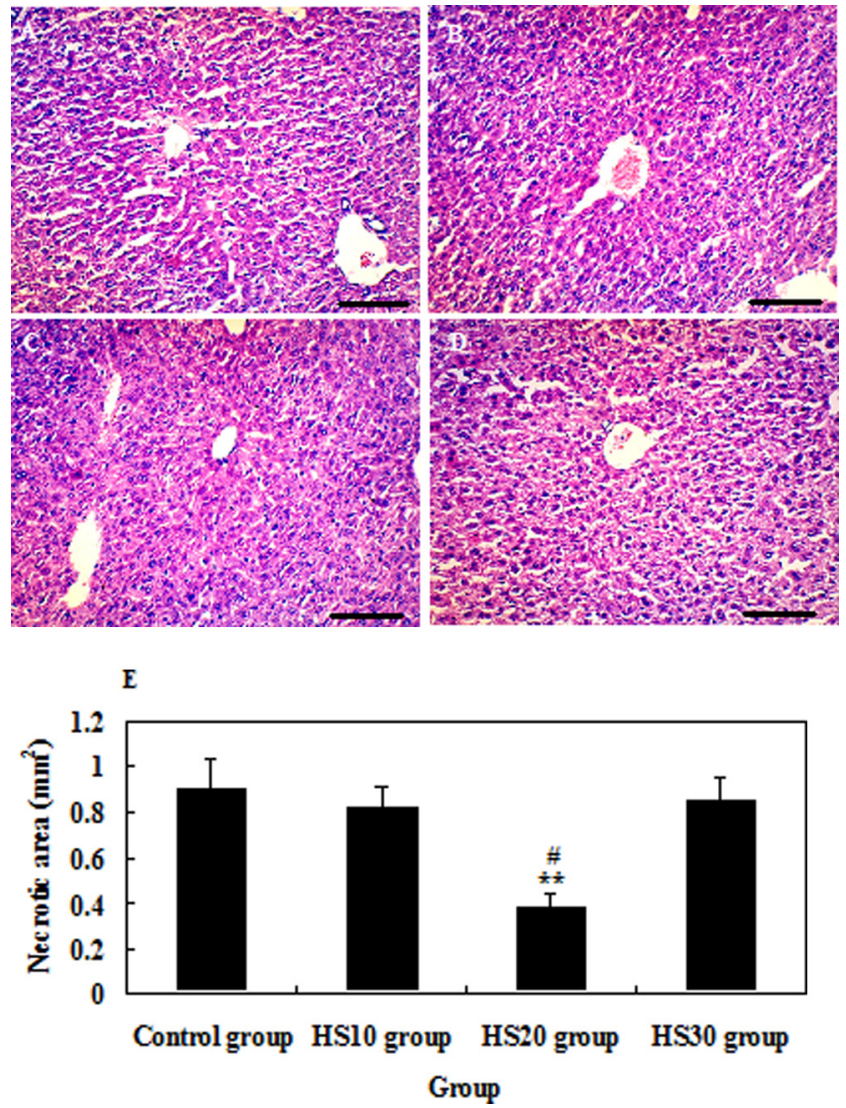

Fig. 3.
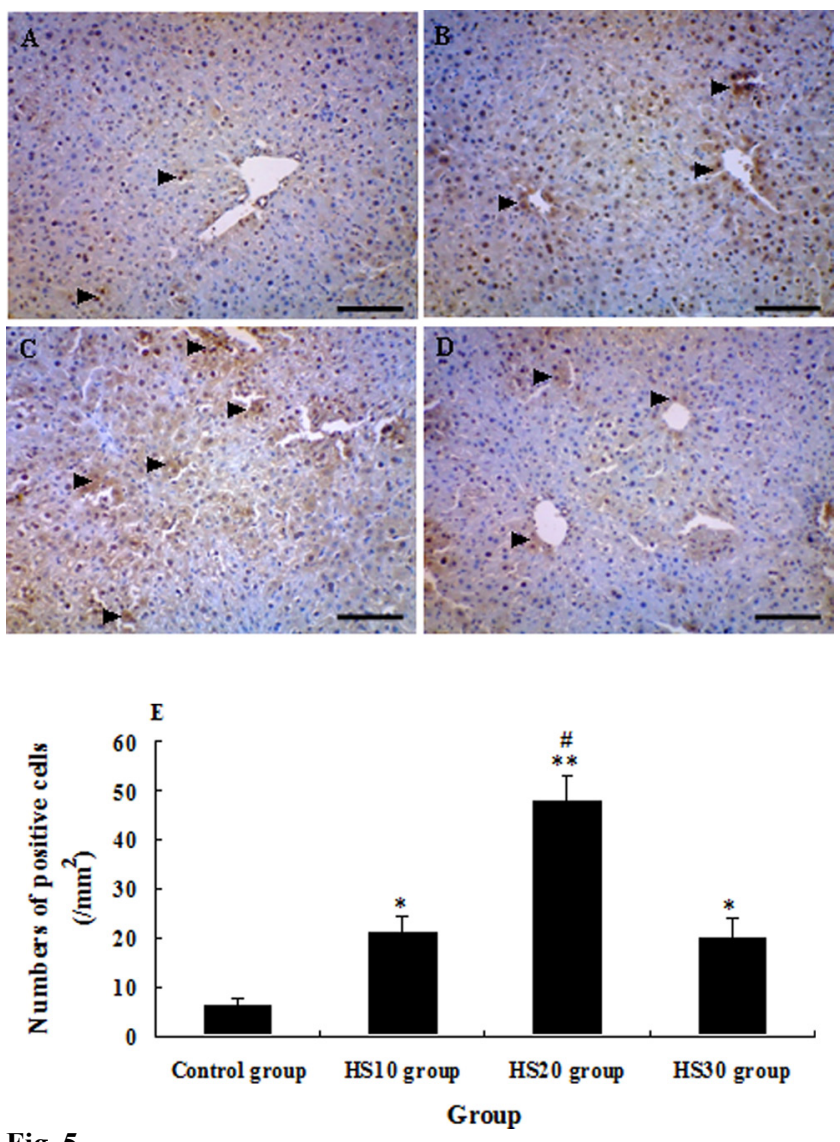

Fig. 5.
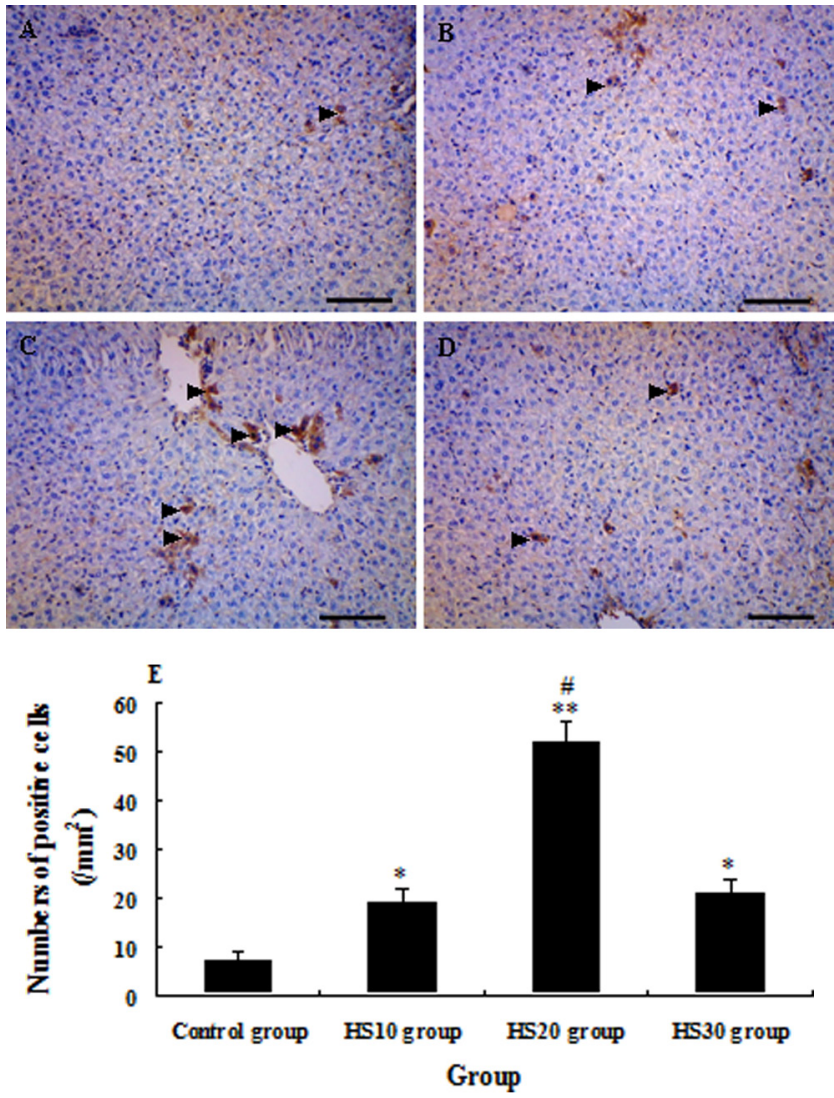

Fig. 4.
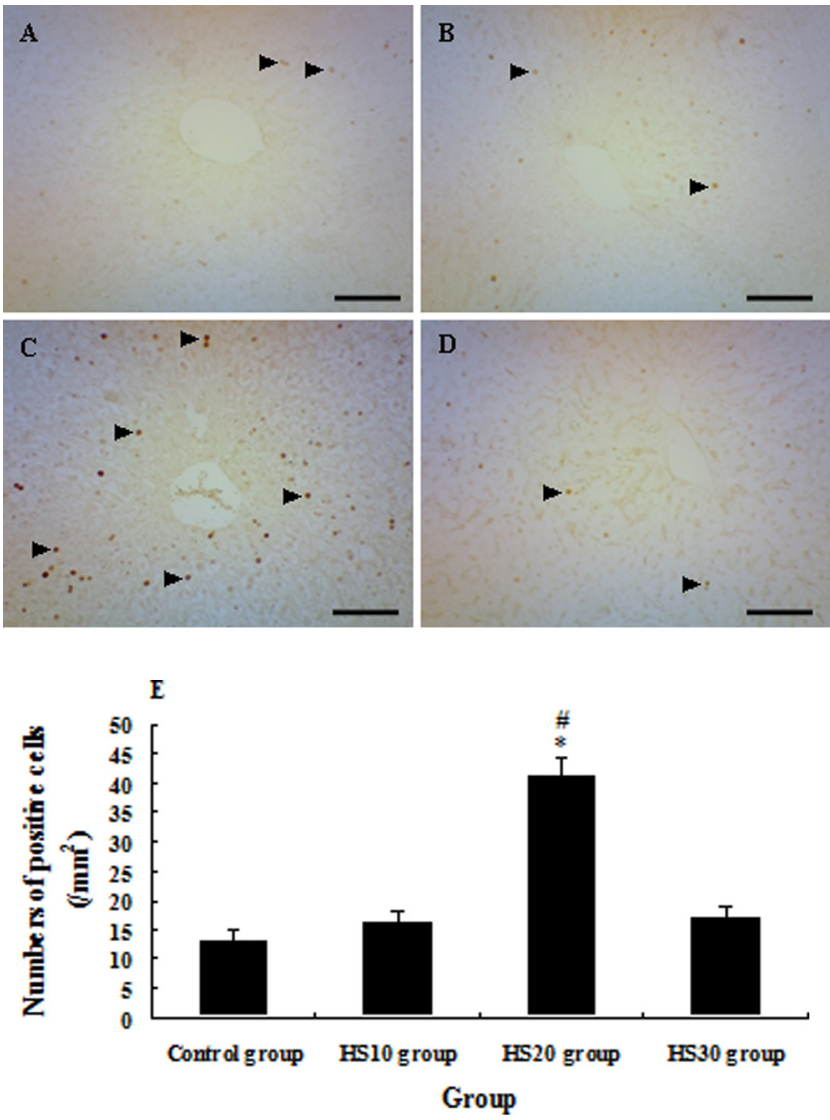

Fig. 6. 

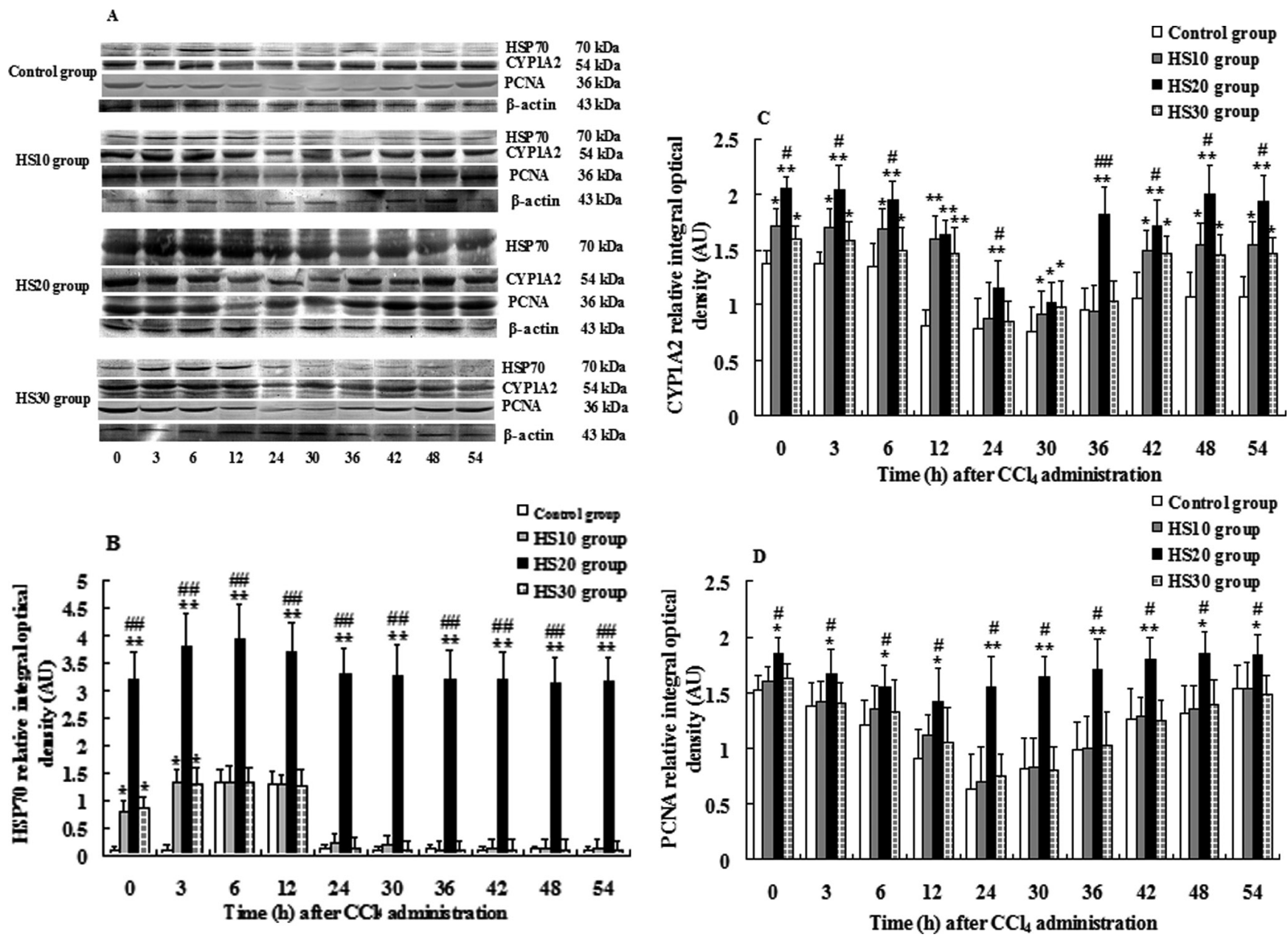

Fig. 7. The expression of HSP70, CYP1A2 and PCNA in the liver of unheated control mice and heat shock-pretreated mice after $\mathrm{CCl}_{4}$ administration. The expression of HSP70, CYP1A2 and PCNA was detected by Western blot (A). The protein bands were quantified for HSP70 (B), CYP1A2 (C) and PCNA (D) with the Gel-Pro Analyzer 4.0 software (Media Cybernetics Inc.) (B), and the intensities of the bands were normalized against $\beta$-actin. AU represents arbitrary unit. Every experiment was repeated three times. All data were presented as the mean \pm standard error of the mean (SEM). ${ }^{\#} P<0.01$; significant difference when compared with the HS10 and HS30 groups.

Fig. 3. Histologic examination of liver injury in mice by $\mathrm{H} \& \mathrm{E}$ staining at $24 \mathrm{~h}$ after $\mathrm{CCl}_{4}$ administration. A, $\mathrm{B}, \mathrm{C}$ and $\mathrm{D}$, respectively, represent the degree of liver injury of mice in the control group, HS10 group, HS20 group and HS30 group after $\mathrm{CCl}_{4}$ administration. E: Necrotic areas. Representative findings from counting with tissue sections that were at least $10 \mathrm{~mm}^{2}$ for each mouse. Scale bar: $50 \mu \mathrm{m}$.

Fig. 4. Photomicrographs of immunohistochemical staining of HSP70 in the liver of unheated control mice and heat shock-pretreated mice at 0 $\mathrm{h}$ after $\mathrm{CCl}_{4}$ administration. The arrowheads indicate the HSP70-positive cells in the liver of mice in the control group (A), HS10 group (B), HS20 group (C) and HS30 group (D). E: Numbers of HSP70 ${ }^{+}$cells in the liver of mice in the control group and preheated groups; tissue sections that were at least $12 \mathrm{~mm}^{2}$ were counted for each mouse. (Scale bar: $50 \mu \mathrm{m}$ ).

Fig. 5. Photomicrographs of immunohistochemical staining of CYP1A2 in the liver of unheated control mice and heat shock-pretreated mice at $0 \mathrm{~h}$ after $\mathrm{CCl}_{4}$ administration. The arrowheads indicate the CYP1A2-positive cells in the liver of mice in the control group (A), HS10 group (B), HS20 group (C) and HS30 group (D). E: Numbers of CYP1A2 ${ }^{+}$cells in the liver of mice in the control group and preheated groups; tissue sections that were at least $12 \mathrm{~mm}^{2}$ were counted for each mouse. (Scale bar: $50 \mu \mathrm{m}$ ).

Fig. 6. Photomicrographs of immunohistochemical staining of PCNA in the liver of unheated control mice and heat shock-pretreated mice at $0 \mathrm{~h}$ after $\mathrm{CCl}_{4}$ administration. The arrowheads indicate the PCNA-positive cells in the liver of mice in the control group (A), HS10 group (B), HS20 group (C) and HS30 group (D). E: Numbers of PCNA ${ }^{+}$cells in the liver of mice in the control group and preheated groups; tissue sections that were at least $12 \mathrm{~mm}^{2}$ were counted for each mouse. (Scale bar: $50 \mu \mathrm{m}$ ). 
$(P<0.01)$ (Figs. 5, 7A and 7C). CYP1A2 is one of the major CYPs in the human liver (approximately 13\%) and metabolizes a variety of clinically important drugs. This enzyme also metabolizes several important endogenous compounds including steroids, retinols, melatonin, uroporphyrinogen and arachidonic acid. Like many of other CYPs, CYP1A2 is subject to induction and inhibition by a number of compounds $^{22}$. Our results demonstrated that proper heat shock preconditioning $\left(40^{\circ} \mathrm{C}\right.$ for $\left.20 \mathrm{~min}\right)$ could effectively induce CYP1A2 expression to improve the metabolic efficiency of the liver, which may be helpful in resisting the damage induced by $\mathrm{CCl}_{4}$ in the liver of mice.

Our results indicated that heat shock preconditioning at $40^{\circ} \mathrm{C}$ for 20 min significantly induced PCNA expression in the liver cells of mice compared with heat shock pretreatment at $40^{\circ} \mathrm{C}$ for $10 \mathrm{~min}$ or $30 \mathrm{~min}$ when compared with control mice $(P<0.05)$ (Figs. 6, 7A and 7D). PCNA is a subunit of the mammalian DNA polymerase delta and is synthesized primarily during the $\mathrm{S}$ phase of the cell cycle ${ }^{23}$. It is a relay or anchoring molecule that functions as a molecular integrator for proteins involved in control of the cell cycle, DNA replication, DNA repair and cell death ${ }^{24,25}$. PCNA has been shown to be a good marker to distinguish proliferating cells ${ }^{17,18}$. So heat shock preconditioning at $40^{\circ} \mathrm{C}$ for 20 min significantly promoted hepatocellular proliferation and accelerated the liver repair after acute liver failure induced by $\mathrm{CCl}_{4}$. Analysis of the above results suggested that both high levels of HSPs and proper heat shock-timing between heat shock pretreatment and $\mathrm{CCl}_{4}$-induced liver injury were critical for optimal protection. Heat shock preconditioning at $40^{\circ} \mathrm{C}$ for 20 min may be helpful in improving the metabolic efficiency of the liver, lowering serum AST and ALT levels and accelerating liver repair after acute liver failure induced by $\mathrm{CCl}_{4}$. But heat shock preconditioning at $40^{\circ} \mathrm{C}$ for 10 min could not sufficiently induce the expression of HSP70, CYP1A2 and PCNA. The stimulation of heat shock preconditioning at $40^{\circ} \mathrm{C}$ for 30 min may be too heavy to induce tolerance of heat in mice.

In conclusion, our study showed that proper heat shock pretreatment ameliorated liver injury and accelerated liver repair after acute liver injury induced by $\mathrm{CCl}_{4}$ in mice, which may be helpful in further investigation of heat shock pretreatment as a potential clinical approach targeting liver injury.

Acknowledgments: This work was supported by grants from the National Natural Science Foundation of China (\#U1204802 and \#81201558) to SQL, Program for Science \& Technology Innovation Talents in Universities of Henan Province (\#13HASTIT025) to SQL and Foundation for Henan Province's Key Project to Tackle Key Problems of Science and Technology (\#122102310030). The authors thank all the members in the laboratory when this work was carried out. The experiments complied with the current laws of China.

\section{References}

1. Yoneyama H, Kai Y, Koyama J, Suzuki K, Kawachi H, Narumi S, and Ichida T. Neutralization of CXCL10 accelerates liver regeneration in carbon tetrachloride-induced acute liver injury. Med Mol Morphol. 40: 191-197. 2007. [Medline]

2. Song JY, Li L, Ahn JB, Park JG, Jo JS, Park DH, Jang HK, Jang JJ, and Lee MJ. Acute liver toxicity by carbon tetrachloride in HSP70 knock out mice. Exp Toxicol Pathol. 59: 29-34. 2007. [Medline]

3. Schiaffonati L, and Tiberio L. Gene expression in liver after toxic injury: analysis of heat shock response and oxidative stress-inducible genes. Liver. 17: 183-191. 1997. [Medline]

4. Shimabukuro T, Yamamoto Y, Kume M, Kimoto S, Okamoto R, Morimoto T, and Yamaoka Y. Induction of heat shock response: effect on the rat liver with carbon tetrachloride-induced fibrosis from ischemia-reperfusion injury. World J Surg. 22: 464-468. 1998. [Medline]

5. Hagiwara S, Iwasaka H, Matsumoto S, Noguchi T, and Yoshioka $\mathrm{H}$. Association between heat stress protein 70 induction and decreased pulmonary fibrosis in an animal model of acute lung injury. Lung. 185: 287-293. 2007. [Medline]

6. Sachidhanandam SB, Lu J, Low KS, and Moochhala SM. Herbimycin A attenuates apoptosis during heat stress in rats. Eur J Pharmacol. 474: 121-128. 2003. [Medline]

7. Fournier S, Kinkead R, and Joseph V. Influence of housing conditions from weaning to adulthood on the ventilatory, thermoregulatory, and endocrine responses to hypoxia of adult female rats. J Appl Physiol. 112: 1474-1481. 2012. [Medline]

8. Mestril R, Chi SH, Sayen MR, O'Reilly K, and Dillmann WH. Expression of inducible stress protein 70 in rat heart myogenic cells confers protection against simulated ischemia-induced injury. J Clin Invest. 93: 759-767. 1994. [Medline]

9. Marber MS, Mestril R, Chi SH, Sayen MR, Yellon DM, and Dillmann WH. Overexpression of the rat inducible $70-\mathrm{kD}$ heat stress protein in a transgenic mouse increases the resistance of the heart to ischemic injury. J Clin Invest. 95: 1446-1456. 1995. [Medline]

10. Plumier JC, Ross BM, Currie RW, Angelidis CE, Kazlaris $\mathrm{H}$, Kollias G, and Pagoulatos GN. Transgenic mice expressing the human heat shock protein 70 have improved postischemic myocardial recovery. J Clin Invest. 95: 1854-1860. 1995. [Medline]

11. Villar J, Edelson JD, Post M, Mullen JB, and Slutsky AS. Induction of heat stress proteins is associated with decreased mortality in an animal model of acute lung injury. Am Rev Respir Dis. 147: 177-181. 1993. [Medline]

12. Williams RS, Thomas JA, Fina M, German Z, and Benjamin IJ. Human heat shock protein 70 (HSP70) protects murine cells from injury during metabolic stress. J Clin Invest. 92: 503-508. 1993. [Medline]

13. Amici C, Giorgi C, Rossi A, and Santoro MG. Selective inhibition of virus protein synthesis by prostaglandin A1: a translational block associated with HSP70 synthesis. J Virol. 68: 6890-6899. 1994. [Medline]

14. Saad S, Kanai M, Awane M, Yamamoto Y, Morimoto T, Isselhard W, Minor T, Troidl H, Ozawa K, and Yamaoka Y. Protective effect of heat shock pretreatment with heat shock protein induction before hepatic warm ischemic injury caused by Pringle's maneuver. Surgery. 118: 510-516. 
1995. [Medline]

15. Li SQ, Li RF, Xi SM, Hu S, Jia ZQ, Li SP, Wen XL, Song YK, Li S, Li SP, Wei FB, and Chen XL. Systematical analysis of impacts of heat stress on the proliferation, apoptosis and metabolism of mouse hepatocyte. J Physiol Sci. 62: 29-43. 2012. [Medline]

16. Zhu RZ, Xiang D, Xie C, Li JJ, Hu JJ, He HL, Yuan YS, Gao J, Han W, and Yu Y. Protective effect of recombinant human IL-1Ra on $\mathrm{CCl}_{4}$-induced acute liver injury in mice. World J Gastroenterol. 16: 2771-2779. 2010. [Medline]

17. Xu CS, Lu AL, Xiong L, and Li GW. Changes of ACP, AKP, HSC70/HSP68 and PCNA in growth and development of rat Liver. Dev Reprod Biol. 9: 1-14. 2000.

18. Assy N, Gong Y, Zhang M, Pettigrew NM, Pashniak D, and Minuk GY. Use of proliferating cell nuclear antigen as a marker of liver regeneration after partial hepatectomy in rats. J Lab Clin Med. 131: 251-256. 1998. [Medline]

19. Sambrook J, and Russell DW. Molecular Cloning: A Laboratory Manual, 4th ed. Cold Spring Harbor Laboratory Press. 256-1260. 2001.

20. Yang YL, Lu KT, Tsay HJ, Lin CH, and Lin MT. Heat shock protein expression protects against death following expo- sure to heatstroke in rats. Neurosci Lett. 252: 9-12. 1998. [Medline]

21. Hillman AR, Vince RV, Taylor L, McNaughton L, Mitchell N, and Siegler J. Exercise-induced dehydration with and without environmental heat stress results in increased oxidative stress. Appl Physiol Nutr Metab. 36: 698-706. 2011. [Medline]

22. Zhou SF, Yang LP, Zhou ZW, Liu YH, and Chan E. Insights into the substrate specificity, inhibitors, regulation, and polymorphisms and the clinical impact of human cytochrome P450 1A2. AAPS J. 11: 481-494. 2009. [Medline]

23. Celis JE, Madsen P, Celis A, Nielsen HV, and Gesser B. Cyclin (PCNA, auxiliary protein of DNA polymerase delta) is a central component of the pathway(s) leading to DNA replication and cell division. FEBS Lett. 220: 1-7. 1987. [Medline]

24. Kelman Z. PCNA: structure, functions and interactions. Oncogene. 14: 629-640. 1997. [Medline]

25. Morrow PW, Tung HY, and Hemmings HC. Rapamycin causes activation of protein phosphatase-2A1 and nuclear translocation of PCNA in $\mathrm{CD}^{+} \mathrm{T}$ cells. Biochem Biophys Res Commun. 323: 645-651. 2004. [Medline] 